\title{
Corrigendum: Broad distribution and high proportion of protein synthesis active marine bacteria revealed by click chemistry at the single cell level
}

\author{
Ty J. Samo *, Steven Smriga ${ }^{\dagger}$, Francesca Malfatti ${ }^{\dagger}$, Byron P. Sherwood ${ }^{\dagger}$ and Farooq Azam \\ Marine Biology Research Division, Scripps Institution of Oceanography, University of California, San Diego, La Jolla, CA, USA \\ *Correspondence: tsamo@hawaii.edu \\ ${ }^{\dagger}$ Present address: Steven Smriga, Ralph M. Parsons Laboratory, Department of Civil and Environmental Engineering, Massachusetts Institute of Technology, \\ Cambridge, USA \\ Francesca Malfatti, Oceanography Section (OCE), National Institute of Oceanography and Experimental Geophysics (OGS), Trieste, Italy \\ Byron P. Sherwood, Department of Oceanography, Center for Microbial Oceanography: Research and Education, School of Ocean and Earth Science and \\ Technology, University of Hawai'i at Mânoa, Honolulu, USA
}

Edited and reviewed by:

Hongyue Dang, Xiamen University, China

Keywords: marine bacteria, microscopy, click chemistry, HPG, single-cell protein production, ecology, oceanography, biogeochemistry

\section{A corrigendum on}

Broad distribution and high proportion of protein synthesis active marine bacteria revealed by click chemistry at the single cell level

by Samo, T. J., Smriga, S, Malfatti, F., Sherwood, B.P., and Azam, F. (2014). Front. Mar. Sci. 1:48. doi: 10.3389/fmars.2014. 00048

The authors wish to include the following section to recognize the support that made this paper possible:

\section{ACKNOWLEDGMENTS}

We would like to thank Jon Cheng and Joseph Villareal for laboratory assistance. We greatly appreciate the helpful suggestions of Peter Franks, the seagoing access and assistance provided by Mark Ohman, and the captain and crew of the R/V Robert Gordon Sproul. This work was funded by grants from the Gordon and Betty Moore Foundation Marine Microbial Initiative (grant \#2758) and the National Science Foundation (award OCE0962721) to Farooq Azam, and a National Science Foundation Ocean Sciences Postdoctoral Research Fellowship to Steven Smriga.

Conflict of Interest Statement: The authors declare that the research was conducted in the absence of any commercial or financial relationships that could be construed as a potential conflict of interest.
Received: 16 October 2014; accepted: 21 October 2014; published online: 10 November 2014.

Citation: Samo TJ, Smriga S, Malfatti F, Sherwood $B P$ and Azam F (2014) Corrigendum: Broad distribution and high proportion of protein synthesis active marine bacteria revealed by click chemistry at the single cell level. Front. Mar. Sci. 1:60. doi: 10.3389/fmars. 2014.00060

This article was submitted to Aquatic Microbiology, a section of the journal Frontiers in Marine Science.

Copyright (C) 2014 Samo, Smriga, Malfatti, Sherwood and Azam. This is an open-access article distributed under the terms of the Creative Commons Attribution License (CCBY). The use, distribution or reproduction in other forums is permitted, provided the original author(s) or licensor are credited and that the original publication in this journal is cited, in accordance with accepted academic practice. No use, distribution or reproduction is permitted which does not comply with these terms. 